\title{
S)
}

ISSN 2278-0211 (Online)

\section{Social Media Use and Moral Development of Students: A Cross-Sectional Survey}

\author{
Dr. Eric Mensah \\ Lecturer, Department of Arts Education, College of Education Studies, \\ University of Cape Coast, Ghana \\ Solomon Kyei \\ Researcher, Department of Arts Education, College of Education Studies, \\ University of Cape Coast, Ghana
}

\begin{abstract}
:
Social media has now become an integral part of human socialization. There is no argument that it offers both the 'good' and the 'bad' and is having a lot of influence on humanity especially the youth. To this end, this study examined the influence of social media usage on the moral development/education of Senior High School students. Focus was on students studying in the Kwabre East Municipality in the Ashanti region of Ghana. Based on the purpose of the study, the descriptive cross-sectional survey design was employed. Respondents for the study were 446 SHS students selected using the proportionate random sampling technique. A self-developed instrument (questionnaire) with a reliability coefficient of 0.87 (Cronbach Alpha) was used for data collection. Both descriptive (frequency counts, percentages, means, standard deviation) and inferential statistics (Point Biserial Correlation) were employed for data analysis. It was revealed among others that, Senior High Schools Students studying in the Kwabre East Municipality use social media for lots of purposes but chiefly for; sharing information, gleaning information, communication and getting new friends. Again, most of them spend between 1-4 hours on social media for the purposes indicated. Also, it was revealed that the students had high levels of moral development but the amount of time spent on social media had a weak negative inverse relationship with their moral development. It was recommended among others that, the Ghana Education Service, Heads of schools and other stakeholders should organize a sensitization programme on social media use for students in senior high schools. This way, social media can be effectively utilised for maximum and positive benefits. Also, an approach is needed to better balance the relationship between social media and moral development/education of students. School authorities and parents should monitor the activities of students on use social media.
\end{abstract}

Keywords: Social media, social media sites, moral development, students

\section{Introduction}

Since creation, human beings have always been socially connected or networked. In the early 21st century, the internet saw the dawn of a new era of information sharing, social media, which is now a growing phenomenon on the internet (O’Reiley, 2007). Social media relates to websites and applications that enable users create and share content or participate in social networking (Merriam-Webster, 2018). It refers to interactive web and mobile phones platforms through which individuals and communities share, co-create, and exchange information, ideas, photos, or videos within a virtual network (Naslund, 2016). There are numerous social media sites that users can choose from. However, in 2017, the top four social media sites were Facebook, WhatsApp, Instagram, and Twitter (Statista, 2017).

In recent times, accessing Facebook, Twitter, Instagram, WhatsApp etc. can be done anywhere and at any time simply by the use of mobile phone (Luik, 2010). In Ghana, the use of social media has risen considerably over the past few years. The growth of social media usage can be tied to the advancement of communication technology in Ghana, that is, the increase in the usage of smartphones and the ease of access to broadband and mobile internet. Students may however form a chunk of social media users in Ghana as research has shown that social media is largely used by young people between the ages of 15-34(Pew Research Centre, 2014) and many students fall within this age bracket therefore majority of them are students. Social media sites have been recognized as an important resource for education as it helps in the sharing of information on relevant education materials within the school or classroom setting. To this end, several software has been developed for e-learning in various jurisdictions using social media. Liccardi, Ounnas, Massey, Kinnunen, Midy, and Sakar (2007) have opined that learners in the school setting connect socially to share their daily learning experiences and have conversations on several topics. However, other studies show that students use social media sites such as Facebook for fun, to kill time, to meet existing friends or to make new ones (Ellison, Steinfield, \& Lampe 2007). However, amidst all the benefits, social media use has regrettably contributed to the moral degeneration 
among students in several countries, including Ghana. While it (social media) has fuelled the level of immorality among the students in the country, new acts of immorality have cropped up as result of the negative influences available on social media sites. Existing literature suggests some of the negative behaviours of social media use such as cyber bullying, internet addiction, indecent dressing, sexual harassment, exposure to indecent content and loss of sacredness of human life and neighbourliness (Sloviter, 2011).According to Kuppuswamy and Shankar (2010), social media sites distract students and turn their attention towards non-educational and inappropriate actions including useless chatting. This ends up making students irresponsible and thus presents a challenge to achieving their educational goals and objectives. Trusov, Bucklin, and Pauwels (2009) from another perspective have said that, the internet is no doubt an evolution of technology but specifically social media sites are extremely unsafe for teenagers especially students. The level of moral decadence in Ghana has become repugnant. The previous invaluable moral values and norms have regrettably been ruined, while immorality now reigns especially among students. Nche (as cited in Yaro, 2013) noted that "gone are the days when morality and discipline used to be virtues. Today it is the exact opposite. People now live in a decadent society where morality and discipline are overboard". This is evident in the current level of sexual promiscuity among the youths in the country. Ani (2002, p.27) has observed that "sexual immorality has become the talk of the day in the country as one is regarded as the greatest by the number of sexual partners he or she has in the name of lovers. As a result, pre-marital sex, and homosexuality are no more vices among students". The phenomenon of social media has ruefully exacerbated the matter "as one can easily reach out to friends of opposite sex, make new ones and even invite them over" through these social media sites (Nche, 2012).Since students form the chunk of users of social media sites, it is likely that their activities on these social media sites may influence taking into their moral development, consideration the amount of time they spent on these social media sites (Morahan-Martin \& Schumacher, 2000; Yermolayeva, \& Calvert, 2009;Jacobson, \& Forste, 2010;Olowu \& Seri, 2012; Olubiyi, 2012). It is evident from the forgoing that, research findings on the influence of social media use on the students' intellectual and moral development are inconclusive.

\section{Context and Purpose of Study}

It is an undeniable fact that social media commands a significant number of users worldwide of which students form a large chunk. In the Ghanaian context, the use of social media sites by Senior High School students has become popular. Wiley and Sisson (2006),have revealed that more than $90 \%$ of students use social media sites.This revelation is confirmed from our experience in senior high schools in Ghana where teachers are always ceasing students' smart phones with a number of social media applications on it. Inasmuch as social media usage gives relevant information to academia, it is also a distractor to many in respect to the development of moral character (Kuppuswamy, \& Shankar, 2010; Sloviter, 2011; Nche, 2012; Umekachikelu, 2013; Markwei, \& Appiah, 2016).

Recent development and experiences in a Senior High Schools indicates that social media use has some negative influence (although inconclusive) on moral development/education of students. This is evident, in the sense that, moral issues such as respect, discipline, honesty, commitment, love, forgiveness, kindness, patriotism, and chastity are somehow missing in the attributes Senior High School students. Recently, Myjoyonline.com reported on 5th July, 2018, that four teachers at Ejisu SHS have been dismissed by Ghana Education Service after some female students accused the teachers of sexually abusing them after a leaked sex video went viral. Also, Adom FM on the 31st of October, 2018, reported that Nkwanta SHS students demonstrated against school authorities because teachers cease their phones which they use for social media.

Several studies (Osharive, 2005; Njoroge, 2013; Nche, 2014) have been conducted elsewhere to investigate the effect of social media use on academic performance of students. Other also looked at social media use, the behaviour of the youth and moral development. In the Ghanaian context, Amofa-Serwaah and Dadzie (2005), Appeanti and Danso (2014), and Otu-Adoasi (2015) all conducted studies on social media use by students but did not concentrate on social media and moral development of students in senior high schools in Ghana. The need to fill this gap in the literature necessitated the examination of the influence of social media use on moral education of senior high school students in the Kwabre East Municipality in the Ashanti Region.

The following research questions directed the study;

- What are the purposes for which Senior High School students studying in Kwabre East Municipality use social media?

- What is the amount of time spent on social media by Senior High School students studying in Kwabre East Municipality?

- What is the level of moral development of Senior High School students studying in Kwabre East Municipality?

- What is the relationship between the amount of time spent on social media and moral development of Senior High School students studying in Kwabre East Municipality?

\section{Methodology}

Research design is a researcher's overall plan for obtaining answers to the research questions or for testing the research hypothesis (Amedahe, \& Gyimah, 2016). The descriptive cross-sectional survey design was adopted for this study. This design allows for the exploration of the current state of a phenomenon and its vivid description (Gall, Gall, \& Borg, 2007; Neuman, 2014; Leavy, 2017). Creswell (2014) opines that the cross-sectional survey allows for the collection of data on a wide range or across board at the same time within a short period of time. This design enabled researchers to collect data from students in all the six senior high schools in the Kwabre East Municipality to determine the extent to which social media use influences their level of moral development. 


\subsection{Sample}

The study focused on students studying in Senior High Schools in the Kwabre East Municipality of the Ashanti Region of Ghana. There are six Senior High Schools in the Municipality. The population for this study comprised of all form two (2) and form three (3) students in all the six Senior High Schools in the Municipality. Students from these forms were chosen because as at the time data was collected the form one (1) had just been admitted. The total population therefore summed up to 3,500. Out of 3,500 students, a sample size of 446 was selected for the study (Krejcie \& Morgan, 1970).

The proportionate sampling technique, where the number of participants from each group is determined by their number relative to the entire population (Leavy, 2017), was used to determine the number of participants (students) from each school. The simple random sampling was then used to select the respondents from each of the six schools. Table 1 contains details of the contribution of each school towards the population in terms of numbers which helped in determining the sample size.

\begin{tabular}{|c|c|c|c|c|}
\hline Name of the School & Male & Female & Population & Sample Size \\
\hline Adanwomase SHS & 280 & 370 & 650 & 83 \\
\hline Adventist Girls SHS & 0 & 500 & 500 & 64 \\
\hline Antoa SHS & 275 & 375 & 650 & 83 \\
\hline Gyaama Pensang SHS & 240 & 360 & 600 & 76 \\
\hline Simms SHS & 250 & 300 & 550 & 70 \\
\hline Kofi Agyei SHS & 210 & 340 & 550 & 70 \\
\hline Total & 1225 & 2245 & 3500 & 446 \\
\hline
\end{tabular}

Table 1: Table of Population and Sample Size

Source: Ghana Education Service, Kwabre East Municipality (2018)

\subsection{Instrument}

The instrument used for the study was a questionnaire. The questionnaire was made up of close ended items. In all, there were 48 closed ended items which were structured into four sections; A, B, C, and D. Section A dealt with sociodemographic background information of the respondents (students) with the remaining sections, B, C, and D covering; the purposes for which Senior High School students use social media, the amount of time spent on social media by Senior High School students and level of moral development of Senior High School students respectively. The instrument was given to colleague researchers to ascertain how they meet face and content validity. A pilot test was also carried out in Bonwire and Ejisu Senior high schools in the Ejisu Juaben Municipality in the Ashanti Region of Ghana. A reliability coefficient of Cronbach's alpha of 0.87 was obtained for the instrument.

\subsection{Analysis}

Data collected using the questionnaires were analysed with Statistical Package for Social Sciences (SPSS 22.0) for windows. Descriptive statistics such as percentages, frequencies, means and standard deviations were used to determine the direction of the responses. Also, Point Biserial correlation was employed to analyse data on the relationship between the amount of time spent on social media and moral development. Results were presented in Tables.

\section{Results and Discussion}

\subsection{Demographics}

Participants for this study were 446 Senior High School students studying in the Kwabre East Municipality in the Ashanti Region of Ghana. There were $192(43.0 \%)$ males and 254 (57.0\%) females. It can be deduced that a greater number of respondents in the study area were females. Also, it may be due to the fact that one of the Senior High School in the study area was a female school, thereby increasing the number of the female respondents. Majority $(n=416 ; 93.3 \%)$ of the respondents were between the ages of 16-21 years. Results on religious affiliation showed that majority $(n=390$; 87.4\%) of the respondents were Christians, followed by Muslims ( $n=55 ; 12.4 \%)$.

\begin{tabular}{|c|c|c|c|}
\hline Demographics & Sub-scale & No. & (\%) \\
\hline Gender & Male & 192 & 43.0 \\
& Female & 254 & 57.0 \\
\hline Age & 15 years and below & 16 & 3.6 \\
& $16-18$ years & 316 & 70.9 \\
& $19-21$ years & 100 & 22.4 \\
& 22 years and above & 14 & 3.1 \\
\hline Religious affiliation & Christian & 390 & 87.4 \\
& Muslim & 55 & 12.3 \\
& Hindu & 1 & .2 \\
\hline
\end{tabular}

Table 2: Demographic Characteristics of Respondents

Source: Field work, (2019) 


\subsection{What Are the Purposes for Which Senior High School Students Studying in Kwabre East Municipality Use Social Media?}

This research question sought to find out the purposes for which senior high school students in the Kwabre East Municipality use social media. It sought to find out if students agreed or disagreed with specific statements made depicting purposes of social media use.

\begin{tabular}{|c|c|c|c|c|}
\hline Statements & $\mathbf{U}$ & SD/D & SA/A & Mean SD \\
\hline & No. \% & No. \% & No. $\%$ & \\
\hline I use social media sites for entertainment & $22 \quad 4.9$ & $78 \quad 17.5$ & 34677.6 & 3.81 .0 \\
\hline Social media helps me to relax & $40 \quad 9.0$ & $146 \quad 32.7$ & $260 \quad 58.3$ & $\begin{array}{ll}3.4 & 1.1 \\
\end{array}$ \\
\hline I use social media sites for direct communication & $20 \quad 4.5$ & $45 \quad 10.5$ & $379 \quad 84.9$ & $4.0 \quad .99$ \\
\hline I use social media to share information & $14 \quad 3.1$ & $27 \quad 6.0$ & $405 \quad 90.8$ & $4.2 \quad .90$ \\
\hline I use social media site to seek information & $18 \quad 4.0$ & 31 & $397 \quad 89.0$ & $4.1 \quad .94$ \\
\hline I connect with family members through social media & $27 \quad 6.1$ & 17.5 & 341 & $3.8 \quad 1.0$ \\
\hline I use social media to learn modern ways of dressing & 6.1 & $118 \quad 26.4$ & 301 & 3.61 .1 \\
\hline I use social media for education on moral issues & 7.8 & $67 \quad 15.0$ & $344 \quad 77.1$ & 3.81 .1 \\
\hline I use social media sites to learn moral issues & 327.2 & 7917.7 & 33575.2 & $3.7 \quad 1.1$ \\
\hline I get educated on moral issues by people on social media & 357.8 & $127 \quad 28.5$ & 28463.7 & $3.5 \quad 1.1$ \\
\hline I use my social media accountto socialize & $31 \quad 7.0$ & $68 \quad 15.2$ & $347 \quad 77.8$ & 3.81 .1 \\
\hline Social media helps me to get new friends & $19 \quad 4.3$ & 9.0 & 38786.8 & 4.1 .99 \\
\hline I use social media sites to repair shaky peer relations & $55 \quad 12.3$ & $172 \quad 38.6$ & $219 \quad 49.1$ & 3.11 .2 \\
\hline I use social media for relationship building & $34 \quad 7.6$ & $171 \quad 38.3$ & $241 \quad 54.0$ & $3.3 \quad 1.2$ \\
\hline I am sexually attracted on social media sites & 368.1 & $252 \quad 56.5$ & $158 \quad 35.5$ & 2.81 .1 \\
\hline I use social media sites for dating & $30 \quad 6.7$ & 257 & 159 & 2.9 \\
\hline I use social media sites to satisfy my sexual needs & 398.7 & 26158.5 & 32.7 & $\begin{array}{ll}2.7 \quad 1.2 \\
\end{array}$ \\
\hline
\end{tabular}

Table 3: Purposes for Using Social Media

Results from Table 3, indicates clearly that statements on information sharing had the highest mean of 4.2 out of 5. Results from the analysis showed that students used social media as a platform to share information. Out of a sample of 446,405 either strongly agreed or agreed $(M=4.2, \mathrm{SD}=0.99)$ that they use social media to share information. Appeanti and Danso (2003) said majority of the students are aware of the existence of social media and use it for various reasons including sharing information. Information seeking $(M=4.1)$ comes next as a purpose for which Senior High School students in the Kwabre East Municipality use social media. Most social media sites have information that may be relevant to learning. Karimi, Khodabandelou, Ehsani and Ahmad (2014) have indicated, by way of affirming this, that information seeking was the highest gratification obtained by Iranian students when they use social media sites. Out of 446 students, 387 either strongly agreed or agreed that they use social media as a conduit for new acquaintances $(M=4.1, S D=0.99)$ all over the world. In substantiating this, Ellison, Steinfield and Lampe (2007) have said that students use social media sites such as Facebook to meet existing friends or to make new ones.

Statements on sexual attraction $(M=2.8, S D=1.1)$, online dating $(M=2.9 ; S D=1.1)$ and satisfaction of sexual needs(M=2.7, $S D=1.2)$ as a purpose of social media use recorded the lowest means in the context and relation to the overall mean. About 252 students out of 446 either strongly disagreed or disagreed that $(\mathrm{M}=2.8, \mathrm{SD}=1.1)$ they use social media sites for sexual attraction. In this sense, Senior High School students in Kwabre East Municipality are aware that it is not good to post nude pictures of themselves or others on social media platforms. The responses of the students may be due to the moral values and norms espoused by the religious and moral education subject which all the students have been exposed to. Again, the Ghanaian societal and cultural context students are affiliated to do not support the idea of posting nude or half naked picture of one on social media platforms. This contradicts Adu-Kumi (2016), who found that students encounter sexual materials (sex clips and nude pictures) mostly through social media platforms. Although majority $(n=252)$ of the respondents disagreed but few also agreed that they use social media sites for such purposes.

\subsection{What Is the Amount of Time Spent on Social Media by Senior High School Students Studying in Kwabre East Municipality?}

This research question sought to find out the amount of time students spend on social media. Students were asked to indicate the number of hours they spend on social daily. Their responses are presented in Table 4.

\begin{tabular}{|c|c|c|}
\hline Time Range & No. & \% \\
\hline 1-2 hours & 121 & 27.1 \\
\hline 3-4 hours & 215 & 48.2 \\
\hline 5-6 hours & 64 & 14.3 \\
\hline 7 hours and above & 46 & 10.3 \\
\hline Total & 446 & 100 \\
\hline
\end{tabular}

Table 4: Amount of Time Students Spend on Social Media in a Day.

It can be inferred from Table 4, that out of 446 students, majority $(n=336)$ spend between one to four hours on social media platforms in a day. One will wonder why students spend such amount of time on social media. It has become 
evident from the findings of research question one that students use social media for information sharing and seeking and also getting new acquaintances. These purposes may be the reasons why students spend such amount of time on social media.Again, 110, (24.6\%) out of 446 said they spend between 5 to 7 hours on social media sites in a day. These prove the relevance and benefits of social media sites in the lives of these students. Students' ability to spend such amount of time confirms the proliferation of smart phones with easy internet access which guarantees frequent and constant surfing of sites. Morahan-Martin and Schumacher (2000) confirm this assertion as they said that, majority of students cannot go for 2- 3 hours without checking and updating their profiles on social media. Congruently, Rideout (2012) has said that, an American child spends on average 7.5 hours a day just for having fun on social media. Failure to control this excessive usage may influence student's life either positively or negatively depending on the purpose of usage.

\subsection{What Is the Level of Moral Development of Senior High School Students in Kwabre East Municipality?}

This research question sought to find out how morally developed Senior High School students in the Kwabre East Municipality are. In this context, their level of moral development was measured based on the features or characteristics of a morally educated person as indicated by Wilson, Downey and Kelly (as cited by Asare-Danso, 2016). Details of results are in Table 5.

\begin{tabular}{|c|c|c|c|c|c|}
\hline Statements & $\mathbf{U}$ & SD/D & SA/A & \multicolumn{2}{|c|}{ Mean SD } \\
\hline & No. \% & No. $\%$ & No. $\%$ & & \\
\hline I am morally matured & $45 \quad 10.1$ & $80 \quad 18.0$ & 32171.9 & 3.6 & 1.2 \\
\hline I am able to make autonomous moral decision & $\begin{array}{ll}58 & 13.0\end{array}$ & 8519.0 & $303 \quad 68.0$ & 3.5 & 1.3 \\
\hline I have a sense of humour & $49 \quad 11.0$ & 10423.3 & $293 \quad 65.7$ & 3.5 & 1.2 \\
\hline My moral character is well shaped & 419.2 & $80 \quad 17.9$ & $325 \quad 72.9$ & 3.8 & 1.2 \\
\hline I am able to form my own moral principles & $39 \quad 8.7$ & $76 \quad 17$ & $331 \quad 74.3$ & 3.8 & 1.2 \\
\hline I have a sense of moral judgment & $50 \quad 11.2$ & $90 \quad 20.3$ & $306 \quad 68.6$ & 3.6 & 1.2 \\
\hline I think in a morally accepted manner & $30 \quad 6.7$ & $63 \quad 4.1$ & $353 \quad 79.1$ & 3.9 & 1.1 \\
\hline I am sensitive to the feelings of other people & 4911.0 & $96 \quad 21.5$ & 30167.5 & 3.6 & 1.2 \\
\hline $\begin{array}{l}\text { I think of the consequences of my actions towards } \\
\text { others }\end{array}$ & $33 \quad 7.4$ & 16.1 & 34176.5 & 3.8 & 1.1 \\
\hline I think about the consequences of my own actions & $38 \quad 8.5$ & $69 \quad 15.5$ & 33976.0 & 3.8 & 1.1 \\
\hline Moral issues are my priority & $42 \quad 9.4$ & 6915.5 & $335 \quad 75.1$ & 3.8 & 1.2 \\
\hline I always learn moral issues of life & $27 \quad 6.1$ & $61 \quad 13.7$ & $358 \quad 80.3$ & 4.0 & 1.0 \\
\hline $\begin{array}{l}\text { Social media use helps predict the outcome of my } \\
\text { actions }\end{array}$ & $59 \quad 13.2$ & 11325.3 & $274 \quad 61.5$ & 3.4 & 1.3 \\
\hline $\begin{array}{l}\text { I take into consideration the interest of others } \\
\text { when it comes to moral issues }\end{array}$ & $46 \quad 10.3$ & 7316.4 & $327 \quad 73.3$ & 3.7 & 1.2 \\
\hline I am able to control my temper on provoking issues & 7.8 & 11124.9 & $300 \quad 67.3$ & 3.6 & 1.2 \\
\hline I share moral issues with my friends & 235.2 & 8619.3 & 75.1 & 3.8 & 1.1 \\
\hline I respect the morals and values of other religions & 184.0 & $67 \quad 15.0$ & 36181.0 & 4.0 & 1.1 \\
\hline
\end{tabular}

Table 5: Students' Level of Moral Development Mean of Means $=3.7$

From Table 5, almost all $(n=358, M=4.0, S D=1.0)$ respondents either strongly agreed or agreed that they are always open to learning moral issues in life. This implies that, students are ready to learn moral lessons of life through their daily experiences both in school and outside school and more especially on social media. This may be due to the fact that respondents are aware that life is governed by moral values of both the society and the religions they are attached to. Therefore, they are mindful that behaviours that are contrary to the societal and religious teachings are in a sense immoral, therefore the individual students are always eager to learn the acceptable actions by both their society and the religion. Majority $(n=361 ; M=4.0, S D=1.1)$ of the students either strongly agreed or agreed that they respect the morals and values of other religions found in their home and school communities. A morally educated person is the one who does not trample on the values and practices of another person's religion and this is exactly what Senior High School students in the Kwabre East Municipality have showed. Ghana is a religiously pluralistic society comprising three major religions namely; Christianity, Islam and African Traditional religion and others. All these religions have similar religious and moral values such as; living a chaste life, respecting those in authority, worshiping God or Allah, and the gods in respect to the African Traditional Religion.

Again, out of 446 students, 353 either strongly agreed or agreed $(M=3.9, S D=1.1)$ that, they do think in an acceptable manner, which is one of the characteristics of a morally educated person. The cognitive aspect of the human life largely depends on what people read, see, where they live, the people they interact with and to some extent, the acceptable laws enforced by the society and the religion to which they belong. Another feature of a morally matured person is the ability to think about the consequences of his/her actions towards others and most of the students ( $\mathrm{n}=341, \mathrm{M}$ $=3.8, \mathrm{SD}=1.1$ ) either strongly agreed or agreed to this. This may be largely due to the fact that respondents are aware actions of students sometimes result in fights, chaos, conflicts and other unacceptable behaviours. It is therefore prudent for them to be mindful of their actions and behaviours towards others. Again, this result may be due to the fact that, students' morals are well shaped based on some lessons taught in religious and moral education class such as: love of your 
neighbour as yourself. Another yardstick for measuring moral development is prioritization of moral issues ( $\mathrm{n}=335$; $\mathrm{M}=3.8, \mathrm{SD}=1.2$ ) which majority of the students either strongly agreed or agreed. The fact that respondents make moral issues their priority may be due to the kind of rules and regulations governing their stay on campus and home as well. This certainly will result in their moral development. Again, the respondents realized the essence of putting their moral issues above all issues because to them, morality supersedes every action in life which therefore brings about peace, harmony and coexistences among people with different faith. Putting results together, it can be conferred from Table 6, that Senior High School students in the Kwabre East Municipality are morally developed based on an overall the mean of 3.7 (SD=1.1) out of 5.0

\subsection{What Is the Relationship between the Amount of Time Spent on Social Media and the Level Moral of Development of} Senior High School Students Studying in Kwabre East Municipality?

This research question was meant to explore the relationship between the amount of time spent on social media (ATSSM) and the level of moral development (MD) of Senior High School students studying in Kwabre East Municipality. To achieve this, the Point Biserial correlation co-efficient was used to analyse data collected from students on the amount of time they spent on social media and their level of moral development. In the analysis, correlation (rpb) was used to determine the degree and the direction of a relationship between the variables (ATSSM and MD). The assumptions for using Point biserial were not violated. The results are shown in Table 6.

\begin{tabular}{|c|c|c|c|c|}
\hline \multicolumn{2}{|c|}{ Variables } & MD & ATSSM & Remarks \\
\hline \multirow{4}{*}{ MD } & PCC value $\left(\mathrm{r}_{\mathrm{pb}}\right)$ & 1 & $-.160^{* *}$ & Negative weak Relationship \\
\cline { 2 - 5 } & Sig. (2-tailed) & & .001 & Significant $(\mathrm{P}<.01)$ \\
\cline { 2 - 5 } & $\mathrm{R}^{2}$ & .123 & & Weak R-Square \\
\cline { 2 - 5 } & $\mathrm{N}$ & 446 & 446 & Sample Size \\
\hline \multirow{4}{*}{ ATSSM } & PCC value $\left(\mathrm{r}_{\mathrm{pb}}\right)$ & $-.160^{* *}$ & 1 & Negative weak Relationship \\
\cline { 2 - 5 } & Sig. (2-tailed) & .001 & & Significant $(\mathrm{P}<.01)$ \\
\cline { 2 - 5 } & $\mathrm{R}^{2}$ & .123 & 446 & Weak R-Square \\
\cline { 2 - 5 } & $\mathrm{N}$ & 446 & Sample Size \\
\hline
\end{tabular}

Table 6: Point-Biserial Relationship between the Times spent on social media and Moral Development ${ }^{* *}$ Correlation Is Significant at the 0.01 Level (2-Tailed)

Results from Table 6 show that, there was negative weak inverse correlation between amount of time spent on social media and moral development, which was statistically significant $(\mathrm{rpb}=-.160 * *, \mathrm{r} 2=.123, \mathrm{n}=446, \mathrm{Sig}=.001, \mathrm{p}<.01-2$ tailed).Practically, the obtained result from PBCC computations means that apparently, students in Kwabre East Municipality who spend much time on social media are likely to exhibits some kind of behaviour that are below societal and religious expectations. In other words, the more time spent on social media, the less morally developed student become and vice versa. Most studies (Chen \& Peng, 2008; Pujazon-Zazik \& Park, 2010; Ahn, 2011; O’Keeffe, Clarke-Pearson \& Council for Communications and Media, 2011; Niculovic et.al 2012; Lou et al., 2012; Nalsund, 2013; Amofa-Dadzie, \& Appiah, 2015) have indicated that users of social media are at a possible risk of cyber bullying, depression, lack of selfcontrol, moral decadence and increased loneliness. Again, the peculiarities of the things these students watch on these social media sites be it pornography, indecent dressing and all other unacceptable cultures have all been acculturated by these students and it has therefore damaged the level of morality among Senior high school students in the Kwabre East Municipality. This proves that, the more students spend time on social media, the more they are exposed to such indecent acts and behaviours therefore affecting their moral development.

\section{Conclusions and Recommendations}

Despite the fact that there are a number of reasons why students use social media sites, sharing of information, seeking or gleaning for information, communication and making new friends seem to top. Senior high school students studying in the Kwabre East municipality demonstrated from their responses that social media has somehow in away ameliorated the issue of information gap mostly referred to as a challenge in teaching and learning. The findings draw attention to the two-sidedness of social media as some responses exposed 'negative' use. Sexual satisfaction and attraction, although recorded very low responses, were some of the reasons why students use social media. The 'good' side of social media outweighs the 'bad' side therefore efforts should be put in place to educate students on its use. The Ghana Education Service, Heads of schools and other stakeholders should organize a sensitization programme on social media use for students in senior high schools. This way, social media can be effectively utilised for maximum and positive benefits. Again, Senior high school students spend a lot of time on social media as their responses indicate that most of them spend between one to seven hours a day. The time spent on social media is related to their purposes for use. By implication, students spend between 1-7 hours daily on social media to; share information, glean information, make new friends, entertain themselves etc. The contention here is not the magnitude of the time on social media but the benefits. Students can be sensitized through education to make good use of their time on social media.

While eye brows are been raised over the effects of social use on students, responses indicated that students were morally developed. Senior high school students studying in the Kwabre East municipality were indicative of the fact that they adhered to societal moral values, rules and norms despite the amount of time they spend on social media. It is argued that the high level of moral development may be due to other factors like social values and norms, plus the content of 
Religious and Moral Education subject that students are exposed to. The Ministry of Education through Ghana Education Service and National Council for Curriculum and Assessment should endeavour to make the teaching of Religious and Moral Education a compulsory subject in Senior High Schools. This will expose students to more learning experiences in moral issues thereby development of moral behaviour.

Interestingly, the amount of time spent on social media has a relationship with the moral development of students. In other words, the level (in terms of time) of social media use by Senior High School students in Kwabre East Municipality has a great influence on their moral development. With a negative weak inverse relationship, students who spent more time on social media were less morally developed as compared to those who spent less time on social media. This indicates that there is a strong morally negative influence of social media use on students. Having in mind the two sidedness of social media, an approach is needed to better balance the relationship between social media and moral development/education of students. School authorities and parents should monitor the activities of students on social media. This is to make sure that students use social media sites for learning and searching of relevant information. Also, awareness on social media applications that are sensitize to moral values and norms can be created for students to utilize them whenever they are online.

\section{References}

i. Adu-Kumi, B. (2016). Sexuality going viral: Using WhatsApp as a site for sexual exploration among College Students in Ghana. Unpublished Master's Thesis. University of Oregon.

ii. Ahn, J. (2011). The effect of social network sites on adolescents' social and academic development: Current theories and controversies. Journal of the American Society for Information Science and Technology, 62(8), 14351445.

iii. Amedahe, F. K., \& Gyimah, E. A. (2016). Introduction to educational research. Centre for Continuing Education, University of Cape Coast, Ghana.

iv. Ani, M. (2002). The youth for the third millennium. Umuahia: HP Press

v. Appeanti, W. O. \& Danso, E. D. (2014). Students' Use of Social Media in Higher Education in Ghana. Innovative Journal. (pp. 3-9).

vi. Chen, Y.F. \& Peng, S. S. (2008). University students' internet use and its relationships with academic performance, interpersonal relationships, psychological adjustment, and self-evaluation. Cyber psychology \&Behavior, vol. (11) 467-46

vii. $\quad$ Creswell, J. W. (2014). A concise introduction to mix methods research. London: Sage Publications.

viii. Downey, M., \& Kelly, A.V. (1979). Moral education: Theory and practice.

ix. $\quad$ Ellison, N., Steinfield, C., \& Lampe, C. (2007). The benefits of facebook "friends:" social capital and college students' use of online social network sites. Journal of Computer-Mediated Communication.

X. Gall, M.D., Gall, J. P., \& Borg, W.R (2007). Educational research: An introduction (8 ${ }^{\text {th }}$ ed.). Toronto: Pearson Education, Inc.

xi. Jacobsen, W., \& Forste, R. (2010). The wired generation: Academic and social outcomes of electronic media use among university students. Cyberpsychology, Behavior, and Social Networking, 45, 275-280

xii. Krejcie, R.V., \& Morgan, D. W. (1970). Determining sample size for research activities. Educational and Psychological Measurement, 2(1) 4-8.

xiii. Kuppuswamy, S., \& Narayan, P. (2010). The Impact of Social Networking Websites on the Education of Youth. International Journal of Virtual Communities and Social Networking (IJVCSN), 2(1), 67-79.

xiv. Liccardi, I., Ounnas, A., Pau, R., Massey, E., Kinnunen, P. Lewthwaite, S., Midy A., \& Sakar, C. (2007). The role of social networks in students' learning experiences. ACM SIGCSE Bull 39(4), 224-237.

xv. Lou, L. L., Yan, Z., Nickerson, A., \& McMorris, R. (2012). An examination of the reciprocal relationship of loneliness and facebook use among first-year college students. Journal of Educational Computing Research, 46(1), $105-117$.

xvi. Luik, J., E. (2010). Social media presentation. Retrieved on December 16, 2018 from: htt://resipotory.petra.ac.id/15386/1/

xvii. Markwei, E. D., \& Appiah, D. (2016). The impact of social media on Ghanaian youth: A case study of the Nima and Maamobi communities in Accra, Ghana. The Journal of Research on Libraries and Young Adults

xviii. Meriam-Webster (2018). Social media. Retrieved on January 2019, from https://www.meriamwebster.comdiong/social\%media

xix. Morahan-Martin, J., \& Schumacher, P. (2000). Incidence and correlates of pathological Internet use among college students. Computers in Human Behavior, 16, 13-29.

xx. Naslund, J. A. (2016). The future of mental health care: Peer-to-peer support and social media. Epidemiology and psychiatric sciences, 25(2), 113-122

xxi. Nche, G. C. (2012). The social media usage among Nigerian youths. Impact on national development. International Journal of Advancement in Development Studies, 7(5), 18-23.

xxii. Niculovic, M., Zivkovic, D., Manasijevic, D. \& Strabac, N. (2012). Monitoring the effect of internet use on students: Technical Faculty Bor, University of Belgrade", Educational Tech Research Dev, (60) 547-559

xxiii. Njoroge, M. (2012). Moral Education in Schools: Is it a worthy undertaking? Paper presented during the 1st Annual International Interdisciplinary Conference, held at Catholic University of Eastern Africa (CUEA), June 2731.

xxiv. O'Reilly, T. (2007). What is web 2.0: Design patterns and business models for the next generation of software. Communications and Strategies, 65(1), 17-37. 
xxv. O'Keeffe. G., Clarke-Pearson, K. \& Council on Communications and Media (2011). The impact of social media on children, adolescents and families. Pediatrics, 124, 800-804.\

xxvi. Olowu, A. O., \& Seri, F. O. (2012). A study of social network addiction among youths in Nigeria. Journal of Social Science and Policy, Review 4, September 2012

xxvii. Olubiyi, S. (2012). Social media and Nigeria youth burden. Retrieved March, 25, 2019.

xxviii. Otu, A. A. (2015). Social media addiction among students of the University of Ghana (Doctoral dissertation, University of Ghana).

xxix. Pew Research Center, (2012). Teens, social media and privacy. Retrieved on October 2018, from. http://www.pewinternet.org/files/2013/05/PIPTeensSocialMediaandPrivacy_PDF.pdf

xxx. Pew Research Center. (2014). Social Networking Fact Sheet. Retrieved December, 14, 2015 from http://www.pewinternet.org/fact-sheets/social-networking-fact-sheet/

xxxi. Rideout, V. (2012). Children, Teens, and Entertainment Media: The View From The Classroom. Common-sense

xxxii. Sloviter, V. (2011). Diagnosis: Social media syndrome. Pediatrics for Parents, 27, 30-31.

xxxiii. Statista. A. (2017). The statistics portal. Retrieved on January 17, 2019 from http: www.statista.com/statistics/270603/worldwide-number-of-hybridand-

xxxiv. Trusov, M., Bucklin, R., \& Pauwels, K. (2009). Effects of word of mouth versus traditional marketing: Findings from an internet social networking site. Journal of Marketing, 73(5), 90-102.

xxxv. Wiley, C., \& Sisson, M. (2006). Ethics, accuracy and assumption: The use of facebook by students and employers. Paper presented at the Southwestern Ohio Council for Higher Education Special Topics Forum, Dayton, $\mathrm{OH}$.

xxxvi. Yaro, J., A. (2013). The story of the northern Ghana. Rural development in northern Ghana 